\title{
Bacterial diversity and community structure in nitrate-contaminated shallow groundwater in the Poyang Lake basin, China
}

\author{
Yihui Dong ${ }^{1,2}$, Jiale $\mathrm{Li}^{1,2}$, Zhanxue Sun ${ }^{1,2, *}$, Evgeniya Soldatova ${ }^{3}$, and Jinjing Zan ${ }^{2}$ \\ ${ }^{1}$ State Key Laboratory of Nuclear Resources and Environment, East China University of Technology, \\ 330013 Nanchang, China \\ ${ }^{2}$ School of Water Resources and Environmental Engineering, East China University of Technology, \\ 330013 Nanchang, China \\ ${ }^{3}$ Research and Education Centre "Water", National Research Tomsk Polytechnic University, 634050 \\ Tomsk, Russia
}

\begin{abstract}
The Poyang Lake basin in the Jiangxi province of China has been exposed to nitrate pollution caused by irrigation practices, leading to high groundwater nitrate concentration. Eight groundwater samples were collected from shallow wells for hydrochemical, bacterial diversity, and community structure analysis in November 2017. Shallow groundwaters of the basin are weakly acid and in an oxidizing state, with EC ranging from 87.6 to $279.5 \mu \mathrm{S} / \mathrm{cm}$ and TDS varying between 53 to $344 \mathrm{mg} / \mathrm{L}$ and averaging of $164 \mathrm{mg} / \mathrm{L}$. The $\mathrm{NO}_{3}-\mathrm{N}$ form is the dominant nitrogen species in groundwater, with concentrations of $\mathrm{NO}_{3}-\mathrm{N}, \mathrm{NO}_{2}-\mathrm{N}$ and $\mathrm{NH}_{4}-\mathrm{N}$ ranging between 2.5 to $164 \mathrm{mg} / \mathrm{L}, 0.01$ to $0.10 \mathrm{mg} / \mathrm{L},<0.01$ to $0.08 \mathrm{mg} / \mathrm{L}$, respectively. Groundwater communities are dominated by actinobacteria, alphaproteobacterial, gammaproteobacteria and betaproteobacteria both in high- and low-nitrate groundwaters. The results of a 16S rRNA gene clone library indicate that the bacterial community structure of the high-nitrate groundwater is different from that of the low-nitrate groundwater. The bacterial populations Denitratisoma and Sulfuritalea detected in lownitrate groundwater suggest that these bacteria are capable of denitrification in anaerobic groundwater environment. Bacterial populations Flavobacteria and Cytophagia in high-nitrate groundwater are common in the s wetlands examined and likely capable of nitrification.
\end{abstract}

\section{Introduction}

Nitrogen contamination in groundwater, mainly nitrate, is a safe-drinking water problem globally in over 110 countries and regions [1]. The largest fresh water natural reservoir in China, the Poyang Lake in the basin of the same name located in Jiangxi province, is exposed to nitrate pollution caused by intense and large-scale irrigation practices. Agricultural activities in this area also lead to nitrate enrichment of the surface

\footnotetext{
*Corresponding author: zhxsun@ecit.cn
} 
water and groundwater. Nitrate concentration in shallow groundwater reaches up to 206 $\mathrm{mg} / \mathrm{L}$ [2], exceeding the WHO recommended value of $11.29 \mathrm{mg} / \mathrm{L}$ for drinking water.

Previous studies indicated that nitrate migration, transformation, and enrichment in groundwater are integrated results of series of microbially mediated reactions and geochemical processes. As one kind of key geological mediators, microorganisms can affect the geochemical behaviour of nitrate in groundwater. Therefore, it is worthy of better understanding of the microbially mediated mechanism of nitrate-contaminated groundwater.

This work investigates the hydrochemical characteristics, bacterial diversity and community structure in nitrate-polluted shallow groundwater in the Poyang Lake basin. This research aims at better understanding the nitrate enrichment mechanisms with the contribution of microorganisms in the aquifer system of the Poyang Lake basin.

\section{Methodology}

\subsection{Study area}

Poyang Lake basin is located in Jiangxi province, southeast China, with an area of $16.2 \times 10^{4}$ $\mathrm{km}^{2}$. The area of Poyang Lake varies in different seasons, covering up to $4,125 \mathrm{~km}^{2}$ in flood season, while as low as $500 \mathrm{~km}^{2}$ in a dry season. It belongs to the subtropical monsoon climate with an average annual temperature of $17.5^{\circ} \mathrm{C}$ and average annual precipitation of 1400-2400 mm.

Groundwater in the Poyang Lake basin is distributed in loose-rock pores, carbonate karst fissures, clasolite karst fissures, and bedrock fissures. Groundwater is primarily recharged by local precipitation, and surface runoff in a wet season, but discharges to rivers in a dry season.

\subsection{Sampling and analysis}

Eight groundwater samples were collected from wells with the depth between 4.6 and $12.1 \mathrm{~m}$ in November 2017 for hydrochemical, bacterial diversity, and community structure analysis. Hydrochemical parameters including temperature $(\mathrm{T}), \mathrm{pH}$, electrical conductivity (EC), oxidation-reduction potential (ORP) and dissolved oxygen (DO) were measured in situ using a portable Analyzer (Hach, HQ40d). Groundwater samples for $\mathrm{NO}_{3}-\mathrm{N}, \mathrm{NO}_{2}-\mathrm{N}$, and $\mathrm{NH}_{4}-\mathrm{N}$ measurement were collected by a syringe and filtered $(<0.45 \mu \mathrm{m})$ into prepared colorimetric reagent solutions and then determined in situ by portable spectrophotometry (Hach, DR2800).

All the 8 samples were treated with the following method. $2 \mathrm{~L}$ of each groundwater sample was filtered on site through a $0.22-\mu \mathrm{m}$ cellulose acetate membrane. The membrane filters were frozen in a portable refrigerator at $-20{ }^{\circ} \mathrm{C}$ until DNA extraction. DNA extractions were carried out using Power Water DNA Isolation (MoBio, Carlsbad, CA 92010, USA). Primer pair 338F (5' -ACTCCTACGGGAGGCAGCAG-3' ) and 806R (5 ' -GGACTACHVGGGTWTCTATT-3' ) were used to amplify bacterial 16S rRNA gene sequences. The purified amplification was quantified using a QuantiFluor ${ }^{\mathrm{TM}}-\mathrm{ST}$ (Promega, Madison, USA) and then pooled together. Samples were sequenced on MiSeq System (Illumina, USA) in Majorbio (Shanghai). 


\section{Results and discussion}

\subsection{Groundwater hydrochemistry}

The main hydrochemical characteristics of 8 groundwater samples are listed in Table 1. These groundwaters have moderate solute contents, with total dissolved solids (TDS) contents of 53 to $344 \mathrm{mg} / \mathrm{L}$ and an average TDS value of $164 \mathrm{mg} / \mathrm{L}$, electrical conductivity values varying between 88 to $279 \mu \mathrm{S} / \mathrm{cm}$, and are weakly acidic with $\mathrm{pH}$ values ranging from 4.1 to 6.8. Their oxidation-reduction potential (ORP) is between 56 to $278 \mathrm{mV}$, indicating an oxidizing groundwater environment. The groundwater sample with a $\mathrm{pH}$ value of 4.1 contains no $\mathrm{HCO}_{3}{ }^{-}$. Concentrations of $\mathrm{NO}_{3}-\mathrm{N}, \mathrm{NO}_{2}-\mathrm{N}$ and $\mathrm{NH}_{4}-\mathrm{N}$ range between 2.5 to $164 \mathrm{mg} / \mathrm{L}, 0.01$ to $0.10 \mathrm{mg} / \mathrm{L},<0.01$ to $0.08 \mathrm{mg} / \mathrm{L}$, respectively. $\mathrm{NO}_{3}-\mathrm{N}$ is the dominant nitrogen species in groundwater, consistent with previous studies [3].

Table 1. A summary of groundwater hydrochemistry.

\begin{tabular}{|c|c|c|c|c|c|c|c|c|c|c|}
\hline & $\begin{array}{c}\mathbf{T} \\
\left({ }^{\circ} \mathbf{C}\right)\end{array}$ & $\mathbf{p H}$ & $\begin{array}{c}\mathbf{E C} \\
(\boldsymbol{\mu s} / \mathbf{c m})\end{array}$ & $\begin{array}{c}\mathbf{O R P} \\
(\mathbf{m V})\end{array}$ & $\begin{array}{c}\mathbf{T D S} \\
(\mathbf{m g} / \mathbf{L})\end{array}$ & $\begin{array}{c}\mathbf{D O} \\
(\mathbf{m g} / \mathbf{L})\end{array}$ & $\begin{array}{c}\mathbf{H C O}_{\mathbf{3}}^{-} \\
(\mathbf{m g} / \mathbf{L})\end{array}$ & $\begin{array}{c}\mathbf{N O}_{\mathbf{3}}-\mathbf{N} \\
(\mathbf{m g} / \mathbf{L})\end{array}$ & $\begin{array}{c}\mathbf{N O}_{2}-\mathbf{N} \\
(\mathbf{m g} / \mathbf{L})\end{array}$ & $\begin{array}{c}\mathbf{N H}_{4}-\mathbf{N} \\
(\mathbf{m g} / \mathbf{L})\end{array}$ \\
\hline Maximum & 22.3 & 6.77 & 605 & 277.7 & 344 & 6.58 & 95.5 & 164.0 & 0.10 & 0.08 \\
\hline Minimum & 19.0 & 4.1 & 87.6 & 56.2 & 53.0 & 3.1 & 0.0 & 2.5 & 0.01 & $<0.01$ \\
\hline Mean & 20.8 & 5.8 & 279.5 & 207.5 & 164.3 & 4.5 & 45.4 & 42.7 & 0.03 & 0.04 \\
\hline
\end{tabular}

\subsection{Bacterial diversity and community structure in groundwater}

As illustrated in Figure 1, bacterial communities in all groundwater samples were dominated by actinobacteria (4.12 to $55.1 \%$ ), alphaproteobacterial (3.2 to $39.2 \%$ ), gammaproteobacteria (1.7 to $21.6 \%$ ) and betaproteobacteria (3.9 to $22.0 \%$ )

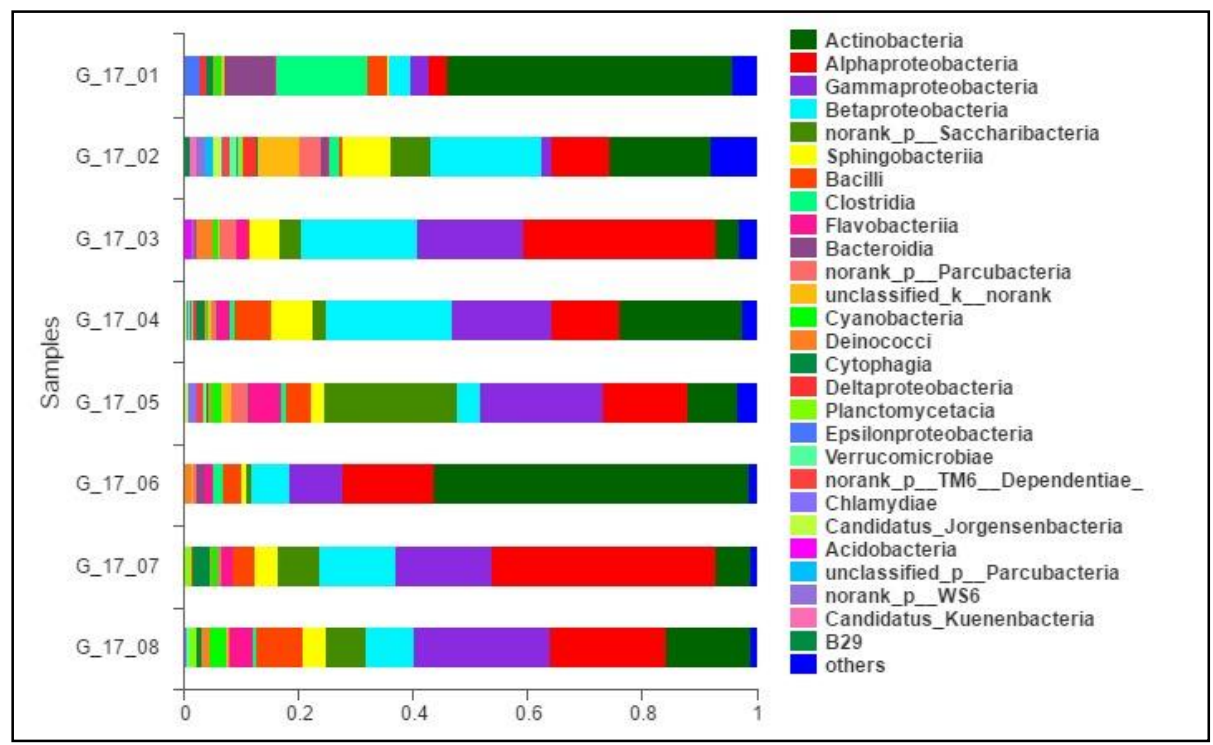

Fig. 1. The bacterial community structure and relative abundance of bacterial classes based on $16 \mathrm{~S}$ rRNA sequence extracted from groundwaters of the Poyang Lake basin.

Results of a 16S rRNA gene clone library indicate that the community structure of highnitrate groundwater is different from that of low-nitrate groundwater (Fig.2.). Besides 
bacterial populations actinobacteria, alphaproteobacterial, gammaproteobacterial and betaproteobacteria, sphingobacteriia is also a dominant population in low nitrate groundwater, sample G-17-02 with $\mathrm{NO}_{3}-\mathrm{N}$ of $2.5 \mathrm{mg} / \mathrm{L}$. Bacterial populations Denitratisoma and Sulfuritalea were found in low nitrate groundwater with a relative abundance of 6.88 and $2.49 \%$, respectively, indicating it is capable of denitrification in aerobic groundwater environment. Bacterial populations including Planctomycetacia, Cytophagia, Bacilli, Sphingobacteriia, cyanobacteria, and flavobacteria are also present in high-nitrate groundwater sample G-17-07, which has a $\mathrm{NO}_{3}-\mathrm{N}$ of $164.0 \mathrm{mg} / \mathrm{L}$. Bacterial populations of Cytophagia and flavobacteria are common in wetlands and capable of nitrification [4]. The genus Limnohabitans is of importance in water eutrophication [5].

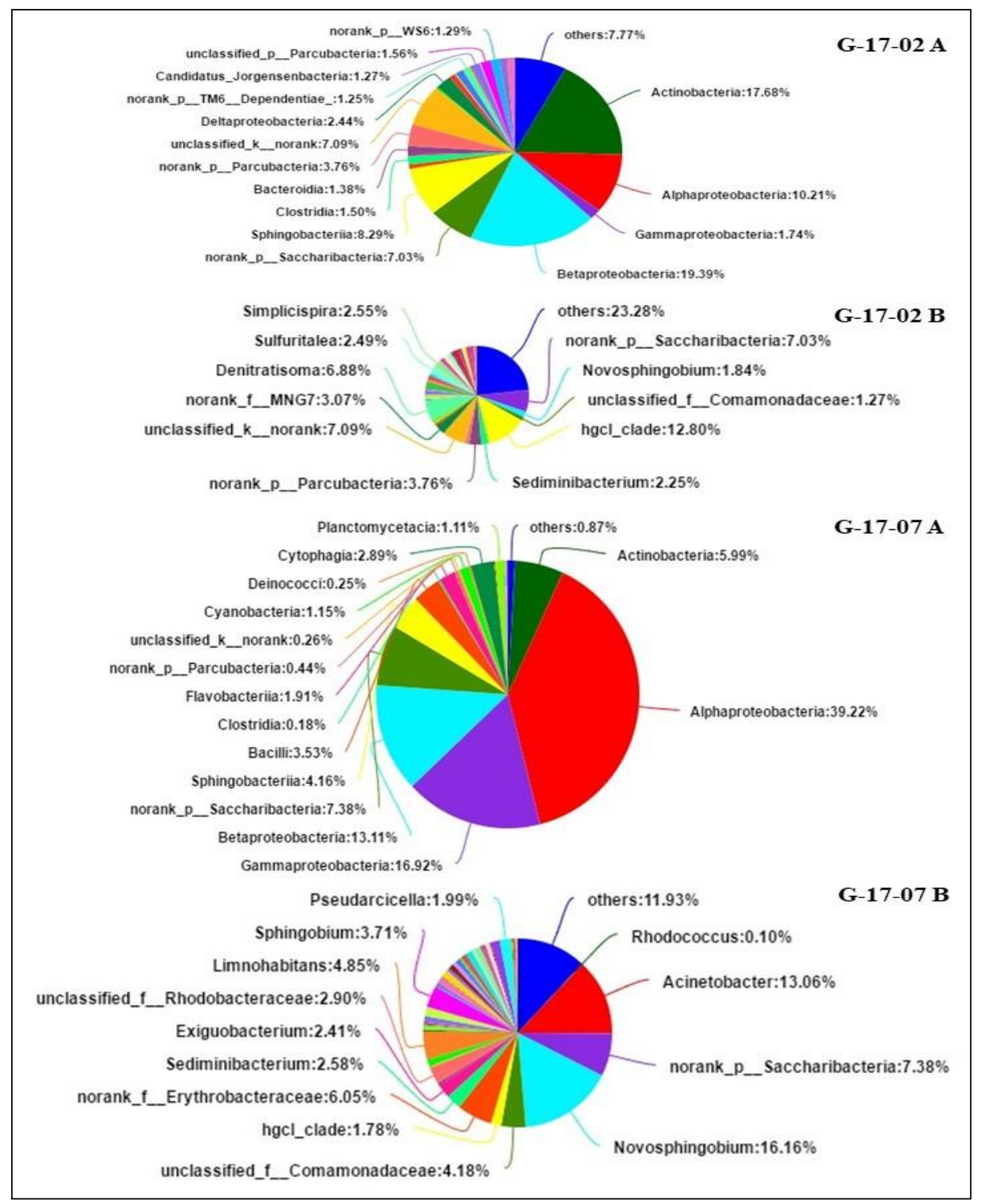

Fig. 2. Comparison of bacterial community structure, based upon the 16S rRNA gene, between groundwater sample G-17-02 with a $\mathrm{NO}_{3}-\mathrm{N}$ concentration of $2.5 \mathrm{mg} / \mathrm{L}$ and sample $\mathrm{G}-17-07$ with $\mathrm{NO}_{3}-\mathrm{N}$ concentration of $164.0 \mathrm{mg} / \mathrm{L}$, (A) classification on a class level; (B) classification on genus level. 
The difference in nitrate concentrations and microbial populations between high- and low-nitrate groundwaters suggests that two possible causes for changing concentrations are microbially-mediated denitrification and nitrification.

\section{Conclusion}

Shallow groundwaters in the Poyang Lake basin are an oxidizing and weakly acid environment where the $\mathrm{NO}_{3}-\mathrm{N}$ form dominates the speciation of nitrogen, and actinobacteria, alphaproteobacterial, gammaproteobacteria and betaproteobacteria dominate the microbial communities. Importantly, the results of $16 \mathrm{~S}$ rRNA gene clone library show the community structure of high-nitrate groundwater is different from that of low-nitrate groundwater, suggesting that different microbially-mediated mechanisms may control the nitrogen enrichment in groundwater.

Acknowledgments. This study was supported by China National Foundation of Natural Sciences (No. 51861145308) and Science and Technology Project Fund of Jiangxi Provincial Education Department (GJJ170443). The study of inorganic nitrogen species was supported by the Russian Science Foundation (RSF), Project No 17-77-10017.

\section{References}

1. X. Chen, et al., Geol Sci Tech Info (in Chinese), 32, 130-149 (2013)

2. E. Soldatova, et al., J Contam. Hydrol, 202, 59-69 (2017)

3. E. Soldatova, et al., Proc Earth Planet Sci, 17, 197-200 (2017)

4. T. Sirivedhin, K.A. Gray, Ecol Eng 26, 167-181 (2006)

5. K.D. McMahon, E.K. Read, Ann Rev Microbiol, 67, 199-219 (2013) 